Academic Platform Journal of Engineering and Science

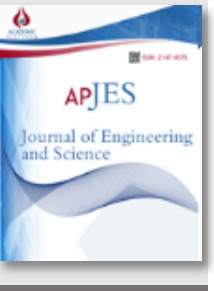

ACADEMIC

$P L A T F O R M$

journal homepage: $\underline{\text { http://apjes.com/ }}$

\title{
Alaşehir (Manisa) Bölgesi Traverten Atıklarının Yol Alttemel ve Temel Tabakalarında Kullanılabilirliğinin Araştırılması
}

\author{
*11Murat Süer, ${ }^{2}$ Ferit Yakar \\ ${ }^{1}$ Milli Savunma Üniversitesi, Hava Astsubay Meslek Yüksek Okulu Müdürlüğü, İzmir, Türkiye, suermurat@hotmail.com, \\ ${ }^{2}$ Tokat Gaziosmanpaşa Üniversitesi İnşaat Mühendisliği Bölümü, Tokat, Türkiye, ferit.yakar@gop.edu.tr, \\ Araștırma Makalesi \\ Geliş Tarihi: 29.09.2019 \\ Kabul Tarihi: 04.05.2020
}

$\ddot{O} \mathbf{z}$

$\mathrm{Bu}$ çalışmada Alaşehir (Manisa) bölgesi traverten atıklarının fiziksel ve mekanik özellikleri tespit edilerek, yol üstyapısında alttemel ve temel malzemesi olarak kullanılabilirliği araştırılmıştır. Araştırma kapsamında traverten atıklarına, Karayolları Teknik Şartnamesi (KTŞ) 2013'de yer alan alttemel ve temel malzeme özelliklerine ait deneyler uygulanmıştır. Bu deneyler; elek analizi, MgSO4 ile yapılan hava tesirlerine karşı dayanıklılık deneyi, Los Angeles aşınma deneyi, yassılık indeksi deneyi, kaba ve ince agregada su emme deneyi, likit limit ve plastik limit deneyi, $\mathrm{NaOH}$ ile yapilan organik madde deneyi, metilen mavisi deneyi, kil topağı ve dağılabilen tane oranı deneyi, proktor ve CBR deneyleridir. Ayrıca traverten atığı malzemenin birim kilometre nakliye bedeli de hesaplanarak maliyet açısından kırmataş malzemeye göre etkin kullanılabilir mesafesi hesaplanmıştır. Sonuçta; traverten atıklarının, KTŞ 2013 standartlarını sağlayarak, alttemel ve temel malzemesi olarak kullanılabileceği görülmüştür. Ayrıca atıklar için bir bedel ödenmediği takdirde belli mesafeye kadar maliyet etkin olduğu ve atıkların yol üstyapısında kullanılmasının taş ocaklarının çevreye vermiş olduğu zararlı etkiyi bir nebze azaltacağı ve böylelikle ülke ekonomisine ve doğal dengeye ilave bir katkı sağlayacağı kanaatine varılmıştır.

Anahtar Kelimeler: Traverten Atıkları, Alt-temel, Temel, Agrega

\section{Investigation of the Usability of Travertine Wastes in Alaşehir (Manisa) Region on Road Subbase and Base Layers}

\author{
*1. Murat Süer, ${ }^{2}$ Ferit Yakar \\ ${ }^{1}$ National Defense University, Air Forces NCO Vocational School, İzmir, Turkey, suermurat@ hotmail.com, \\ ${ }^{2}$ Tokat Gaziosmanpaşa University, Civil Engineering Department, Tokat, Turkey, ferit.yakar@gop.edu.tr,
}

\begin{abstract}
In this study, physical and mechanical properties of travertine wastes in Alaşehir (Manisa) region were determined and their usability as sub-base and base material was investigated. Within the scope of the research, experiments related to the sub-base and base material properties in the Technical Specifications of Highways (TSH) 2013 were applied to the travertine wastes. These experiments; sieve analysis, weather resistance test with MgSO4, Los Angeles abrasion test, flatness index test, water absorption test in coarse and fine aggregate, liquid limit and plastic limit test, organic material test with $\mathrm{NaOH}$, methylene blue test, clay pellet and dispersible grain ratio test, proctor and CBR experiments. In addition, the unit kilometer transportation cost of travertine waste material was calculated and the effective usable distance was calculated in terms of cost compared to crushed stone material. After all; it is seen that travertine wastes can be used as subbase and base material by meeting TSH 2013 standards. In addition, it is considered that unless a price is paid for the wastes, it is cost effective up to a certain distance and that the use of wastes in the road superstructure will reduce the harmful effects of the quarries to the environment to some extent and thus contribute to the national economy and natural balance.
\end{abstract}

Keywords: Travertine Wastes, Sub-base, Base, Aggregate

\section{GÍRIS}

Karayolu, altyapı ve üstyapıdan oluşan bir sistemdir. Yol üstyapıs1; genellikle alttemel, temel ve esnek ya da rijit

${ }^{* 1}$ Sorumlu yazar: Milli Savunma Üniversitesi, Hava Astsubay Meslek Yüksek Okulu Müdürlüğü, İzmir, Türkiye, suermurat@ hotmail.com, 0 2322511600 
kaplama tabakasından oluşmaktadır. Alttemel ve temel tabakalarının teşkilinde çoğunlukla taş ocaklarından temin edilen kırmataş malzemeler kullanılmaktadır. Yol yapım maliyeti, asfalt bitümünün ülkemize ithal olarak gelmesi sebebiyle yüksek seviyelerdedir. Maliyetlerin aşağılara çekilebilmesi için; atık malzemelerin imalatlara girmesi önem arz etmektedir. Aynı zamanda kullanılacak atık malzemelerin teknik bakımdan alttemel ve temel tabakas için öngörülen Karayolları Teknik Şartnamesi (KTŞ) 2013 'de yer alan standart değerleri de sağlaması gerekmektedir.

Bu çalışmada, Alaşehir (Manisa) bölgesi traverten atıklarının yol üstyapısında alttemel ve temel tabakalarında agrega olarak kullanılabilirliği incelenmiştir.

Ülkemizde traverten denildiğinde akıllara ilk olarak Denizli ili, Pamukkale ilçesi gelmektedir. Pamukkale travertenleri, UNESCO Dünya Kültür Mirası Listesinde yerini almış, görsel güzelliğiyle dünya çapında değeri olan doğal taş oluşumlarıdır. Manisa ili Alaşehir ilçesi de Pamukkale’ye çok da uzak olmayan ve Maden Tetkik Arama Genel Müdürlüğünün Manisa ili maden ve enerji kaynakları verilerine göre 99.7 milyon ton muhtemel traverten rezervine sahip bir bölgede yer almaktadır.

Traverten, Türk Dil Kurumu sözlüğünde; birtakım kaynak sularının dibinde biriken, kalkerli veya silisli tortu, pamuk taşı şeklinde açıklanan, dilimize Fransızcadan geçmiş bir kelimedir. Fransizca "travertin", İtalyanca "travertino", İngilizce "travertine" olarak adlandırılır. Traverten, özünde doğal bir taş olduğundan, konuya doğal taş tanımından başlamak daha uygun olacaktır.

Doğal taşlar, kayaç olarak da adlandırılan, doğadan çıkan ve birtakım işlemler gördükten sonra kullanılan yapı malzemeleridir. Doğal taşlar, dayanıklılık özelliğiyle tarih boyunca yapıların inşasında kullanılmışlardır. Yapıda, doğal enerjili haliyle kullanılabilen nadir inşaat malzemelerindendir. Kullanım alanları çok geniştir, inşaat sektöründe kaplama, döşeme, kırmataş olarak kullanıldığ gibi birçok farklı sektörde de kullanımı mevcuttur.

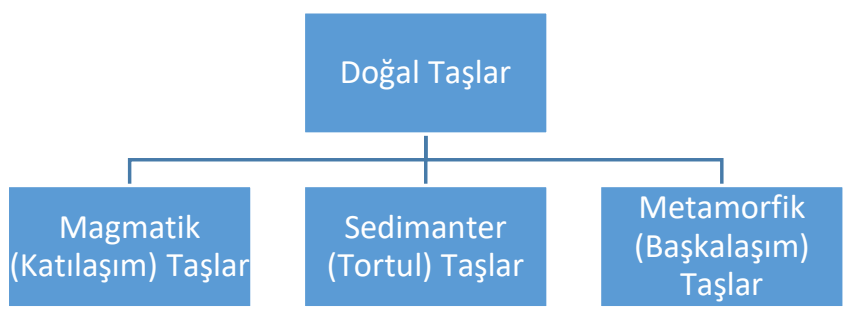

Şekil 1. Doğal taşların sınıflandırılması

Doğal taşlar, dünyanın 4.6 milyar yıl öncesindeki durumundan başlayarak dağların, denizlerin, okyanusların, nehirlerin oluşum evrelerindeki kimyasal, biyolojik değişimler, iklim şartları, erozyon olaylarının bir sonucu olarak farklı sıkışma, aşınma, taşınmalar neticesindeki değişimleriyle alt sınıflara ayrılırlar. Şekil 1'de doğal taşların sinıflandırılması görülmektedir.

Sedimanter oluşumlu mermerlerden traverten ve oniksler; bileşiminde erimiş halde kalsiyumbikarbonat ve karbondioksit bulunduran sulardan oluşmuş kayaçlardır. Bu yeraltı sularının yeryüzüne çıkması ile kayacın bileşimindeki karbon gaz haline geçerek suyu terk eder. $\mathrm{Bu}$ arada kalsiyumbikarbonat bileşimli katı madde şekillenir. Bu şekillenme olayı soğuk su vasıtası ile oluşursa "oniks", sıcak su vasıtası ile oluşursa "traverten" adını alırlar. Travertenler inşaatlarda iç ve dış kaplama malzemesi olarak kullanılırlar. Az cila kabul eden kayaçlardır [1]

Literatürde, traverten atıklarının karayolu temel ve alttemel tabakalarında agrega olarak kullanımıyla ilgili olarak yapılmış çalışma sayısı fazla değildir. Bununla birlikte, travertene benzer bir malzeme olan mermerin kullanımı konusunda yapılmış bazı çalışmalar da mevcuttur.

Yıldız (2008) yaptığı doktora tez çalışmasında, mermer toz ve parça atıklarının yol inşaatında değerlendirilebilirliğini araştırmıştır. Çalışma kapsamında parça atıkların yol temel tabakasında, toz atıkların ise zemin toprağı içerisine karıştırılarak stabilizasyonda kullanılabilirliği test edilmiştir. Analiz sonuçlarından toz atıkların zemin stabilizasyonunu artırdığı ve ince taneli atıkların iyi performans gösterdiği belirlenmiştir. Genellikle homojen tane dağılımına sahip atıklar mukavemeti artırmıştır. Parça atıklar için elde edilen analiz sonuçlarında, temel tabakası için yollar fenni şartnamesinde belirtilen şartların sağlandığı, ancak traverten gibi yumuşak yapıya sahip parça atıkların don etkisi göstermeyen sıcak bölgelerde kullanılmasının daha uygun olacağ1 görülmüştür [2]

Çoruh ve ark. (2013) yaptıkları çalışmada bor cevheri olan kolemanitten borik asit üretimi esnasında ortaya çıkan borojips atığının, yol üstyapılarındaki alttemel tabakalarında bağlayıcı madde olarak kullanımı araştırmışlardır. Çalışma kapsamında borojips atığı ile alttemel malzemesi farklı oranlarda karıştırılarak elde edilen numuneler üzerinde serbest basınç ve CBR deneyleri yapılmıştır. Sonuç olarak esnek üstyapılarda borojips kullanımıyla, üstyap1 maliyetinin ve bor atığının sebep olduğu çevre kirliliğinin azalabileceği görülmüştür [3]

Çobanoğlu ve ark. (2014) yaptıkları çalışmada Denizli bölgesi traverten artıklarının beton agregası olarak kullanılabilirliğinin incelemişlerdir. Çalışma kapsamında ocak üretiminden çıkan parça şeklindeki travertenlerin betonda agrega olarak kullanılabilirliği araştırılmıştır. Sonuçlar traverten agregalı betonun hedeflenen C30 sınıfı beton dayanım değerlerini sağladığını göstermiştir [4]

Ural ve Yakşe (2015) yaptıkları çalışmada mermer ocağı sayısı çok fazla olan Bilecik İlindeki mermer atıklarının, yol temel malzemesi olarak değerlendirilmesini araştırmışlardır. Deneylerde kullanılan mermer atıkları, Karayolları Teknik 
şartnamesinde belirtilen temel malzemesi gradasyonu aralıklarında hazırlanarak, şartnamede belirtilen fiziksel özellikleri taşıyıp taşımadıkları kontrol edilmiştir. Sonuçta, Bilecik İlinin üç farklı bölgesinden alınan mermer atıklarının Karayolları Teknik şartnamesinde belirtilen alttemel/temel malzemesi fiziksel özelliklerini sağladığg görülmüştür [5]

Yakşe (2016) yaptığ 1 yüksek lisans tez çalışmasında, atık mermer parçalarının yol temel malzemesi olarak değerlendirilmesini araştırmıştır. Bilecik İlindeki mermer atıklarının, yol temel malzemesi olarak değerlendirilmesine yönelik deneyler yapmıştır. Sonuçta, Bilecik İlinin üç farklı bölgesinden alınan mermer atıklarının Karayolları Teknik Şartnamesinde (KTŞ, 2013) belirtilen alt temel/temel malzemesi fiziksel özelliklerini sağladığ 1 ve CBR eğrilerinin de şartnameye uygun olduğu görülmüştür [6].

Özdemir ve ark. (2017) yaptıkları çalışmada, Doğu Anadolu bölgesinde bulunan bazı mermer atıklarının yol temel ve alttemel tabakalarında kullanılabilirliğini incelemişlerdir. Mermer üretim atığı olarak Malatya Bej, Adıyaman Emprador ve Erzurum Traverten numuneleri kullanmışlar, araştırmalarının sonucunda, malzemenin temel ve alt temel tabakalarında kullanılabilir olduğu görülmüştür [7]

Yüksek ve Kaya (2017) yaptıkları çalışmada Sivas Kangal Termik santrali uçucu külü ile alçı ve kirecin değişik oranlarda karışımları ile hafif yapı malzemesi üretimi deneysel olarak araştırmışlardır. Çalışma sonucunda Tüm numunelerin yoğunluk ile eğilme mukavemeti arasında yüksek korelosyonlu $\left(\mathrm{R}^{2}=0,95\right)$ doğrusal ilişki olduğu, Shore sertlik değeri ile eğilme mukavemeti arasında üssel bir ilişki $\left(\mathrm{R}^{2}=0,81\right)$ olduğu görülmüştür [8]

Ergezer (2018) yaptığı çalışmada, Sivas ili Sıcak Çermik Bölgesi traverten atıklarının karayollarının temel ve alt temel tabakalarında kullanılabilirliğini araştırmıştır. Deney sonuçlarının KTŞ, 2013'de belirtilen sınır değerleri sağladığı görülmüştür [9]

Yılmaz (2020) yaptığı çalışmada uçucu kül ve mermer tozu atıklarını, katı atık yönetimi kapsamında zemin stabilizasyonu için kullanmıştır. Çalışma sonucunda, uçucu kül+mermer tozu karışımlarının sadece uçucu kül içeren karışımlara göre daha yüksek dayanım sağladığı sonucuna varılmıştır [10]

Sarışık ve ark. (2020) yaptıkları çalışmada traverten atıklarının çimentolu dolgu malzemesi olarak kullanımında renk ve parlaklık değerlerini araştırmışlardır. Çalışma kapsamında, endüstriyel fabrikadan alınan 4 farklı reçete ile laboratuvar çalışmaları sonucunda oluşturulan reçeteler renk ve parlaklık açısından karşılaştırılmıştır. Yeni reçetelerde renk ve parlaklık açısından daha uyumlu ve daha ekonomik olduğu için traverten atıkları kullanılmıştır. Sonuç olarak renk ve parlaklık açısından orijinal plaka yüzeylerine yakın yeni yüzeyler elde edilmiştir [11].
Bunlardan başka; yol temel ve alttemel tabakalarında çeşitli atık malzemelerin kullanımını ele alan bazı çalışmalar (Yonar ve ark., 2017 [12]; Motor, 2017 [13]; Seren,2015 [14]; Yılmaz ve Sütaş, 2008 [15]) ile traverten (veya mermer) atıklarının beton veya yol sıcak karışımında kullanımını ele alan çeşitli çalışmalar (Korkmaz, 2017 [16]; Okubay, 2016 [17]; Güven, 2015 [18]; Ceylan ve Mança, 2013 [19]; Gürer, 2005 [20]) da mevcuttur.

\section{MATERYAL VE YÖNTEM}

\subsection{Materyal}

Çalışmada, karayolu temel ve alttemel tabakalarında traverten atıklarının kullanılması ele alınmıştır. Bu amaçla, Alaşehir (Manisa) bölgesindeki traverten ocaklarından traverten atığ 1 malzeme temin edilmiştir. Yaklaşık $150 \mathrm{~kg}$ traverten atığı numunesi laboratuvar ortamında taş kırma yöntemi ile uygun dane boyut aralığına getirilmiştir.

\subsection{Yöntem}

Türkiye'de karayollarının yapımında kullanılacak malzemelerin, uygunluğunun kontrol edilmesi amaciyla başvurulacak temel kaynak, Karayolu Teknik Şartnamesidir. Dolayısıyla, çalışmanın konusu olan, traverten atığı malzemenin alttemel ve temel tabakalarında agrega olarak kullanılabilirliğinin belirlenebilmesi için de KTŞ 2013'de belirtilen deneyler yapılarak malzemenin fiziksel ve mekanik özelliklerinin şartnamedeki değerlere uygun olup olmadığı kontrol edilmiştir. Bu kapsamda yapılan deneyler şunlardır:

- Elek analizi deneyi,

- MgSO4 ile yapılan hava tesirlerine karşı dayanıklılık deneyi,

- Los Angeles aşınma deneyi,

- Yassılık indeksi deneyi,

- Kaba ve ince agregada su emme deneyi,

- Likit limit ve plastik limit deneyi,

- $\mathrm{NaOH}$ ile yapılan organik madde deneyi, Metilen mavisi deneyi,

Kil topağı ve dağılabilen tane oranı deneyi, Proktor ve CBR deneyleri.

\section{DENEYSEL ÇALIŞMALAR VE BULGULAR}

Aşağıda, yapılan her bir deneyin yapılma amacı ve hangi standardın esas alındığı belirtilmiştir. Deney sonuçları ve bu sonuçların uygunluk durumu da gerekli tablolar ve grafiklerle birlikte sunulmuştur.

\subsection{Elek analizi deneyi}

Elek analizi malzemenin uygun gradasyon limitleri içerisinde olup olmadığını belirlemek için yapılan bir deneydir. Deneyde TS EN 1900-1[21] standardı esas alınmıştır. 
Traverten atı̆̆ incelendiğinde; malzemenin KTŞ 2013'de yer alan, alttemel ve temel malzeme olarak kullanılabilmesi için gerekli olan şartlara uygun olduğu tespit edilmiştir. Şekil 2'de alttemel, Şekil 3'de ise temel numunesinin gradasyon dağılımı görülmektedir.

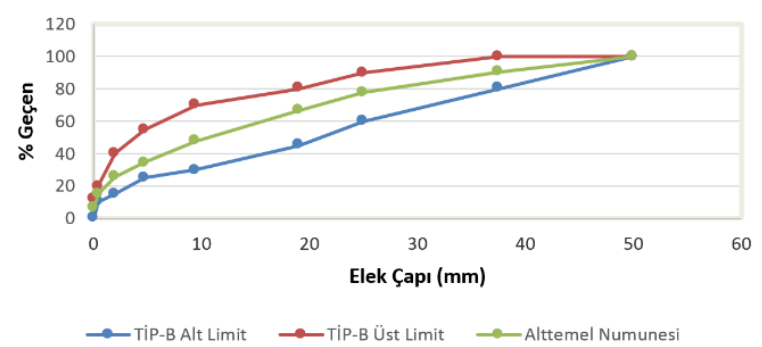

Şekil 2. Alttemel numunesi gradasyon dağılımı

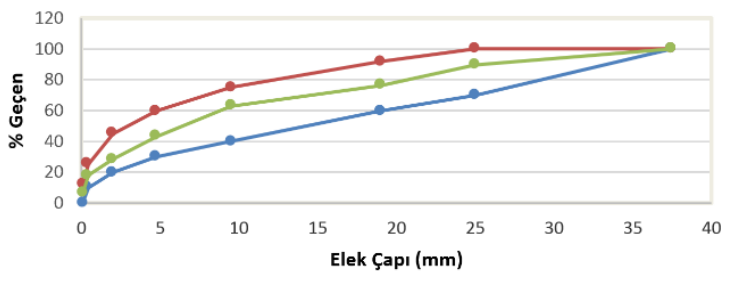

$\rightarrow$ TiP-B Alt Limit $\rightarrow$-Tip-B Üst Limit $\rightarrow$ Temel Numunes

Şekil 3. Temel numunesi gradasyon dağılımı

\subsection{MgSO4 ile yapılan hava tesirlerine karşı dayanıklılık deneyi}

Deneyde, agregaların magnezyum sülfat çözeltisine daldırılması ve takiben kurutulmasıyla periyodik işleme maruz bırakılarak donma/çözülme etkisine karşı direncinin bulunması amaçlanmaktadır. Deneyde TS EN 1367-2[22] standardı esas alınmıştır. Deney sonucuna göre, traverten atığı malzemenin hem alttemel hem de temel tabakalarında kullanılabilir olduğu görülmüştür. Tablo 1'de $\mathrm{MgSO} 4$ ile hava tesirlerine dayanıklılık deney sonucu görülmektedir.

Tablo 1. MgSO4 ile hava tesirlerine dayanıklılık deney sonucu

\begin{tabular}{|c|c|c|c|}
\hline $\begin{array}{c}\text { Numune } \\
\text { Malzeme }\end{array}$ & $\begin{array}{c}\text { KTŞ 2013 } \\
\text { Limit }\end{array}$ & $\begin{array}{c}\text { Deney } \\
\text { Sonucu, \%MS }\end{array}$ & Sonuç \\
\hline Alttemel & $\leq 25$ & 13 & Uygundur \\
\hline Temel & $\leq 20$ & 13 & Uygundur \\
\hline
\end{tabular}

\subsection{Los Angeles aşınma deneyi}

Deney, iri agregaların parçalanma direncinin tayini için yapılmaktadır. Deneyde TS EN 1097-2[23] standardı esas alınmıştır. Deney sonucuna göre, traverten atığı malzemenin hem alttemel hem de temel tabakalarında kullanılabilir olduğu görülmüştür. Deney sonucu Tablo 2'de verilmiştir.

Tablo 2. Los Angeles aşınma deney sonucu

\begin{tabular}{|c|c|c|c|}
\hline $\begin{array}{c}\text { Numune } \\
\text { Malzeme }\end{array}$ & $\begin{array}{c}\text { KTŞ 2013 } \\
\text { Limit }\end{array}$ & $\begin{array}{c}\text { Deney } \\
\text { Sonucu, LA }\end{array}$ & Sonuç \\
\hline
\end{tabular}

\begin{tabular}{|c|c|c|c|}
\hline Alttemel & $\leq 45$ (LA45) & 28 & Uygundur \\
\hline Temel & $\leq 35$ (LA35) & 28 & Uygundur \\
\hline
\end{tabular}

\subsection{Yassılık İndeksi Deneyi}

Deney, kalınlığı (en küçük boyutu) nominal boyutunun 0.6 'sından daha küçük olan kaba agrega danelerinin (63-6.3 mm elek aralığındaki) yassılık indeksi değerinin bulunmasını amaciyla yapılmaktadır. Deneyde BS 812[24] standardı esas alınmıştır. Deney sonucuna göre, traverten atığı malzemenin hem alttemel hem de temel tabakalarında kullanılabilir olduğu görülmüştür. Deney sonucu Tablo 3'de verilmiştir.

Tablo 3. Yassilık indeksi deney sonucu

\begin{tabular}{|c|c|c|c|}
\hline $\begin{array}{c}\text { Numune } \\
\text { Malzeme }\end{array}$ & $\begin{array}{c}\text { KTŞ 2013 } \\
\text { Limit }\end{array}$ & $\begin{array}{c}\text { Deney } \\
\text { Sonucu, Yİ }\end{array}$ & Sonuç \\
\hline Alttemel & $\leq 35$ & 10.88 & Uygundur \\
\hline Temel & $\leq 30$ & 10.88 & Uygundur \\
\hline
\end{tabular}

\subsection{Kaba ve İnce Agregada Su Emme Deneyi}

Deney, kaba ve ince agregada su emme oranının tayini için yapılmaktadır. Deneyde TS EN 1097-6 (Madde 8) [25] standardı esas alınmıştır. Deney sonucuna göre, traverten atığı malzemenin hem alttemel hem de temel tabakalarında kullanılabilir olduğu görülmüştür. Deney sonuçları, alttemel için Tablo 4, temel malzeme için ise Tablo 5'de verilmiştir.

Tablo 4. Kaba ve ince agrega su emme deney sonucu (alttemel)

\begin{tabular}{|c|c|c|c|}
\hline $\begin{array}{c}\text { Numune } \\
\text { Aralığı, mm }\end{array}$ & $\begin{array}{c}\text { KTŞ } 2013 \\
\text { Limit, Alttemel }\end{array}$ & $\begin{array}{c}\text { Su Emme, } \\
\% \text { WA }\end{array}$ & Sonuç \\
\hline $31.5-63$ & \multirow{3}{*}{$\leq 3.5$} & 2.38 & \multirow{3}{*}{ Uygundur } \\
\hline $4-31.5$ & & 1.04 & \\
\hline $0.063-4$ & & 0.81 & \\
\hline
\end{tabular}

Tablo 5. Kaba ve ince agrega su emme deney sonucu (temel)

\begin{tabular}{|c|c|c|c|}
\hline $\begin{array}{c}\text { Numune } \\
\text { Aralığ } 1, \mathrm{~mm}\end{array}$ & $\begin{array}{c}\text { KTS } 2013 \\
\text { Limit, Temel }\end{array}$ & $\begin{array}{c}\text { Su Emme, } \\
\% \text { WA }\end{array}$ & Sonuç \\
\hline $31.5-63$ & \multirow{3}{*}{$\leq 3.0$} & 2.38 & \multirow{3}{*}{ Uygundur } \\
\hline $4-31.5$ & & 1.04 & \\
\hline $0.063-4$ & & 0.81 & \\
\hline
\end{tabular}

\subsection{Likit Limit Deneyi ve Plastisite İndeksi}

Likit Limit deneyi, numunenin plastik durumdan likit (sıv1) duruma geçtiği andaki su muhtevası değerinin bulunması amaciyla yapılmaktadır.

Plastik limit deneyi ise numunenin plastik kıvamda bulunduğu en düşük su muhtevasının tespiti için yapılmaktadır. Traverten atıklarına plastik limit deneyi uygulanmıştır. Deneyde TS 1900-1[21], AASHTO T 89[26] ve AASHTO T 90[27] standardı esas alınmıştır. 
Plastik limit deney sonucunda traverten atığ plastik özellik göstermediği tespit edilmiştir. Bu sebeple malzemeye likit limit deneyi uygulanmamıştır. Likit limit ve plastisite indeksi değeri non-plastik olarak alınmıştır. Deney sonucuna göre, traverten atığı malzemenin hem alttemel hem de temel tabakalarında kullanılabilir olduğu görülmüştür. Tablo 6'da likit limit, Tablo 7'de ise plastisite indeksi deney sonucu verilmiştir.

Tablo 6. Likit limit deney sonucu

\begin{tabular}{|c|c|c|c|}
\hline $\begin{array}{c}\text { Numune } \\
\text { Malzeme }\end{array}$ & KTŞ 2013 Limit & $\begin{array}{c}\text { Deney } \\
\text { Sonucu, WP }\end{array}$ & Sonuç \\
\hline Alttemel & $\leq 25$ & NP & Uygundur \\
\hline Temel & Non-plastik, NP & NP & Uygundur \\
\hline
\end{tabular}

Tablo 7. Plastisite indeksi deney sonucu

\begin{tabular}{|c|c|c|c|}
\hline $\begin{array}{c}\text { Numune } \\
\text { Malzeme }\end{array}$ & $\begin{array}{c}\text { KTŞ 2013 } \\
\text { Limit }\end{array}$ & $\begin{array}{c}\text { Deney } \\
\text { Sonucu, IP }\end{array}$ & Sonuç \\
\hline Alttemel & $\leq 6$ & NP & Uygundur \\
\hline Temel & $\begin{array}{c}\text { Non-plastik, } \\
\text { NP }\end{array}$ & NP & Uygundur \\
\hline
\end{tabular}

\section{7. $\mathrm{NaOH}$ ile Yapılan Organik Madde Deneyi}

Deney, agrega içerisinde yer alan bitki artıkları ve humus gibi organik maddelerin tespit edilebilmesi için yapılmaktadır. Deneyde TS EN 1744-1 (Madde 15.1) [28] standardı esas alınmıştır. Deney sonucuna göre, traverten atığı malzemenin hem alttemel hem de temel tabakalarında kullanılabilir olduğu görülmüştür. Tablo 8'de deney sonucu, Şekil 4'de ise deney sonuç fotoğrafı görülmektedir.

Tablo 8. $\mathrm{NaOH}$ ile yapılan organik madde deney sonucu

\begin{tabular}{|c|c|c|c|}
\hline $\begin{array}{c}\text { Numune } \\
\text { Malzeme }\end{array}$ & $\begin{array}{c}\text { Karışım } \\
\text { Rengi }\end{array}$ & $\begin{array}{c}\text { Organik } \\
\text { Madde }\end{array}$ & Sonuç \\
\hline Temel & Renksiz & Hiç yok & Uygundur \\
\hline Alttemel & Renksiz & Hiç yok & Uygundur \\
\hline
\end{tabular}

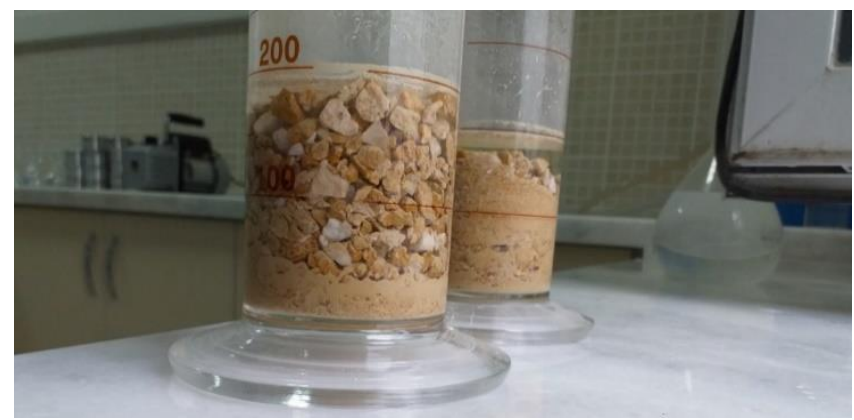

Şekil 4. $\mathrm{NaOH}$ ile yapılan organik madde deney fotoğrafı

\subsection{Metilen Mavisi Deneyi}

Deney, ince agreganın (0-2 mm) içerisindeki kil ve silt gibi zararlı malzemelerin değerinin tespit edilebilmesi için yapılmaktadır. Deneyde TS EN 933-9[29] standardı esas alınmıştır. Deney sonucuna göre, traverten atığı malzemenin hem alttemel hem de temel tabakalarında kullanılabilir olduğu görülmüştür. Tablo 9'da deney sonucu, Şekil 5'de ise deney sonuç fotoğrafi görülmektedir.

Tablo 9. Metilen mavisi deney sonucu

\begin{tabular}{|c|c|c|c|}
\hline $\begin{array}{c}\text { Numune } \\
\text { Malzeme }\end{array}$ & $\begin{array}{c}\text { Şartname } \\
\text { Limit }\end{array}$ & $\begin{array}{c}\text { Deney } \\
\text { Sonucu, } \\
\mathrm{MB}\end{array}$ & Sonuç \\
\hline Alttemel & $\leq 4,0$ & 1 & Uygundur \\
\hline Temel & $\leq 3,0$ & 1 & Uygundur \\
\hline
\end{tabular}

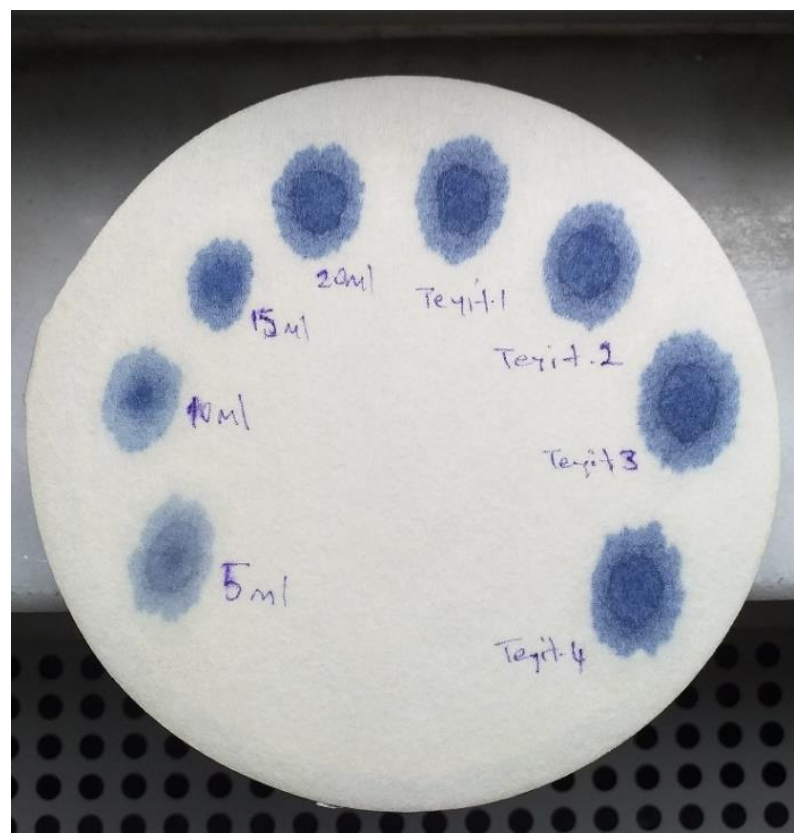

Şekil 5. Metilen mavisi deneyi süzgeç kâğıdı görüntüsü

\subsection{Kil Topağı ve Dağılabilen Tane Oranı Deneyi}

Deney, kaba ve ince agregada kil topağı ve dağılabilen tane oranını tespit etmek için yapılmaktadır. Deneyde ASTM C 142[30] standardı esas alınmıştır. Deney sonucu Tablo 10'da verilmiştir.

Tablo 10. Kil topağı ve dağılabilen tane oranı deney sonucu

\begin{tabular}{|c|c|c|c|}
\hline $\begin{array}{c}\text { Numune } \\
\text { Malzeme }\end{array}$ & $\begin{array}{c}\text { Şartname } \\
\text { Limit, } \\
\% \mathrm{P}\end{array}$ & $\begin{array}{c}\text { Kil topağı ve } \\
\text { dağılabilen tane } \\
\text { oranı, \%P ort. }\end{array}$ & Sonuç \\
\hline Alttemel & $\leq 2,0$ & 0.31 & Uygundur \\
\hline Temel & $\leq 1,0$ & 0.31 & Uygundur \\
\hline
\end{tabular}

\subsection{Modifiye Proktor ve CBR Deneyleri}

KTŞ 2013 Alttemel ve temel malzeme kullanım kriterlerinde CBR değerinin tespit koşulu yer almaktadır. CBR deneyinin ise modifiye proktor deneyinde bulunan optimum su muhtevasında yapılması gerekmektedir.

Modifiye proktor deneyi, alttemel ve temel tabakasında kullanılacak malzemenin modifiye proktor metodu ile sıkıştırılmış, en büyük kuru birim hacim ağırlığını veren su muhtevası değerinin bulunması için yapılmaktadır. Deneyde AASHTO T 180[31], TS 1900-1[21] standardı esas 
alınmıştır. Deneyde elde edilen kuru birim havim ağırlık ve optimum su muhtevası değerleri Tablo 11'de verilmiştir.

Tablo 11. Modifiye proktor deney sonucu

\begin{tabular}{|c|c|c|c|}
\hline $\begin{array}{c}\text { Tokmak } \\
\text { kütlesi }\end{array}$ & $4.5 \mathrm{~kg}$ & Kalıp çapı, mm & 101.6 \\
\hline $\begin{array}{c}\text { Kuru birim } \\
\text { hacim ağırlık }\end{array}$ & $\begin{array}{c}23.90 \\
\mathrm{kN} / \mathrm{m}^{3}\end{array}$ & $\begin{array}{c}\text { Kalıp yüksekliği, } \\
\mathrm{mm}\end{array}$ & 116.4 \\
\hline Wopt, \% & 7.6 & Kalıp hacmi, $\mathrm{cm}^{3}$ & 944 \\
\hline
\end{tabular}

Kaliforniya taşıma oranı (CBR), bir toprağın dikkatle kontrol edilen yoğunluk ve rutubet şartları altında daneler arası kayma direncinin bir ölçüsüdür [32]. Deney, optimum su içeriğine sahip numunenin pistonla belli bir noktaya kadar batması için gereken basıncın bulunması için yapılmaktadır. Deneyde AASHTO T 193[33], 1900-2[34] standardı esas alınmıştır. Deney sonucuna göre, traverten atığ malzemenin hem alttemel hem de temel tabakalarında kullanılabilir olduğu görülmüştür. Deney sonucu Tablo 12'de verilmiştir.

Tablo 12. Kaliforniya taşıma oranı (CBR) deney sonucu

\begin{tabular}{|c|c|c|c|}
\hline $\begin{array}{c}\text { Numune } \\
\text { Malzeme }\end{array}$ & $\begin{array}{c}\text { Şartname } \\
\text { Limit, } \%\end{array}$ & $\begin{array}{c}\text { Bulunan Yaş } \\
\text { CBR, } \%\end{array}$ & Sonuç \\
\hline Alttemel & $>50$ & 238 & Uygundur \\
\hline Temel & $>100$ & 238 & Uygundur \\
\hline
\end{tabular}

\section{MALIYET HESAPLAMALARI}

$\mathrm{Bu}$ bölümde, traverten atıkları ve kırmataşın yol alttemel ve temel tabakalarında kullanılabilmesi için ortaya çıkan üretim ve nakliye maliyetleri incelenmiştir.

\subsection{Traverten Atığı ve Kırma Taş İçin Üretim Maliyeti Hesabı}

Taş ocaklarında, kaya parçalarını kullanılabilir boyutlara getirmek için sabit konkasör tesisleri kullanılmaktadır. Kırmataş talep edilen karışım oranlarına uygun olarak temin edilmektedir. Tablo 13'de taş ocağında kırmataş hazırlama 2020 yılı birim fiyatı verilmiştir.

Tablo 13. Ocaktan taş hazırlanması poz fiyatı

\begin{tabular}{|c|c|c|c|}
\hline Poz Numaras1 & Açıklama & Birim & Fiyat1, TL \\
\hline KGM/08.021/ & Ocaktan taş & $\mathrm{m}^{3}$ & 17.81 \\
\cline { 3 - 4 } K-(T) & hazırlanması & ton & 9.89 \\
\hline
\end{tabular}

Traverten taş ocağında ve traverten kesme işleme tesislerinde sabit konkasör sistemine ihtiyaç duyulmamaktadır. Traverten atıklarının alttemel veya temel malzemesi olarak kullanılabilmesi için mobil konkasörde kırılması ya da sabit konkasörü olan bir tesise taşınması gerekecektir.

Her iki yöntemde de traverten atığının uygun boyutlara getirilmesi için, kırmataş hazırlama maliyetinden fazla bir maliyet çıkması söz konusudur. Söz konusu maliyet iş bazında yapılması gerektiğinden hesaplanmamıştır.

\subsection{Traverten Atı̆̆ı Malzeme ve Kırma Taş İçin Nakliye Maliyeti Hesabı}

Nakliye bedeli Çevre ve Şehircilik Bakanlığınca her yıl yayınlanan birim fiyat kitapçı̆̆ında yer alan taşıma formülleri kullanılarak hesaplanmaktadır. Nakliye bedeli hesap birimi tondur. Alttemel ve temel malzeme ihtiyac1 hacimsel alan hesabı yapılarak, $\mathrm{m}^{3}$ biriminden belirlenmektedir.

TS 825 Binalarda Isı Yalıtımı [35] standardından alınan traverten ve kırmataş için birim hacim kütle verileri Tablo 14'de verilmiştir. Tablo 14'de bakıldığında traverten ve kırmataşın, bir metreküp ağırlıklarının farklı olduğu görülmektedir.

Tablo 14. Traverten-kırmataş birim hacim kütle değerleri

\begin{tabular}{|c|c|}
\hline Malzeme & Birim hacim a $\breve{g} ı$ ılı̆ $1, \mathrm{~kg} / \mathrm{m}^{3}$ \\
\hline Traverten & 2600 \\
\hline Kırmataş & 1800 \\
\hline
\end{tabular}

Nakliye bedeli hesab1:

F: Nakliye bedeli

$\mathrm{K}$ : Motorlu araç taşıma katsayısı

M: Mesafe, ( $\leq 10 \mathrm{~km}$ : metre, $>10 \mathrm{~km}$ : kilometre $)$

$\leq 10.000$ m.ye kadar motorlu araçlarla yapılan taşımalarda kullanılacak formül;

$$
F=0.00017 * K * \sqrt{M}
$$

$>10 \mathrm{~km}$. için motorlu araçlarla yapılan taşımalarda kullanılacak formül;

$$
F=K *((0.0007 * M)+0.01)
$$

2020 Yılı Çevre ve Şehircilik Bakanlığınca yayınlanan birim fiyatlarda, her cins ve tonajda motorlu araç taşıma katsayısı (K), 380 olarak verilmektedir.

$\mathrm{Bu}$ değerler kullanılarak traverten ve kırmataşın farklı mesafeler için hesaplanan $1 \mathrm{~m}^{3}$ nakliye bedeli Tablo 15'de verilmiş, Şekil 6'da grafik olarak gösterilmiştir.

Tablo 15. Farklı mesafeler için malzeme $1 \mathrm{~m}^{3}$ nakliye bedeli

\begin{tabular}{|c|c|c|c|}
\hline Malzeme & $10 \mathrm{~km}, \mathrm{TL}$ & $30 \mathrm{~km}, \mathrm{TL}$ & $70 \mathrm{~km}, \mathrm{TL}$ \\
\hline Traverten & 16.80 & 30.62 & 58.29 \\
\hline Kırmataş & 11.63 & 21.20 & 40.36 \\
\hline Fark & 5.17 & 9.42 & 17.94 \\
\hline
\end{tabular}

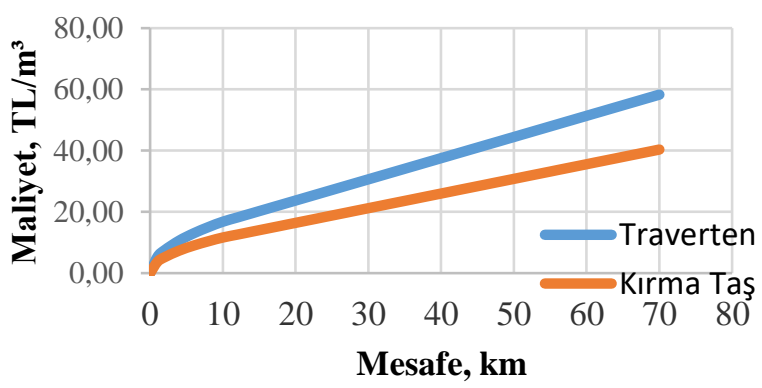

Şekil 6. Traverten- kırmataş mesafe-maliyet grafiği

Tablo 15 ve Şekil 6 'nın incelenmesi sonucunda; $1 \mathrm{~m}^{3}$ malzeme için; taşıma mesafesi arttıkça, traverten atığı 
malzemenin, kırma taşa oranla nakliye maliyetinin arttığ görülmüştür. Tablo 13 'de verilen kırmataş maliyet değerlerini göz önüne aldığımızda; $30 \mathrm{~km}$ mesafeye yapılan taşımalarda yaklaşık 1 ton kırmataş bedeli kadar, $70 \mathrm{~km}$ mesafeye yapılan taşımalarda ise $1 \mathrm{~m}^{3}$ kırmataş bedeli kadar taşıma maliyet farkının oluştuğu görülmüştür. Buna göre, traverten atı̆̆ 1 için bedel ödenmediği varsayılsa bile, traverten atığını alttemel ve temel tabakalarının yapımı için kullanacağımız mesafe artışıyla, taşıma maliyetindeki artışın doğru orantılı olarak arttığ 1 gözlemlenmiştir.

\section{TARTIŞMA VE SONUÇ}

Traverten atığı malzeme, traverten taş ocaklarında ya da traverten işleme tesislerinde ortaya çıkmaktadır. Travertenin kaplama malzemesi olarak kullanılabilmesi için belli ebatlara getirilmesi gerekmektedir. Bu sebeple taş ocağından çıkarılması, büyük bloklar halinde hazırlanması ve işleme tesislerinde kaplama malzemesi ebatlarına getirilmesi esnasında çıkan fire malzeme atık olarak ayrıştırılmaktadır. Atık malzemeler bu tesislerin çevresinde stok halinde depolanmakta ve çevre kirliliğine sebebiyet vermektedir.

Taş ocaklarında ortalama $100 \mathrm{~m}^{3}$ traverten alanı boşaltıldığında $15 \mathrm{~m}^{3}$ traverten çıkarılmaktadır. Bu da ocak veriminin \%15 olduğunu göstermektedir. Fabrikalarda ise üretim verimi \%30'lara kadar düşmektedir. Moloz şeklinde fabrikalara gelen travertenlerden \%70'e kadar atık oluşabilmektedir. Bu atıklar hem fabrikalara ilave maliyet oluşturmakta hem de tarımı olumsuz yönde etkilemektedir [36].

Depolandığı yerlerde çevre üzerinde büyük tahribat yaratan traverten atıklarının, imalata dönüşmesi amacıyla yol temel ve alttemel tabakalarında kullanılması durumunda traverten ocak ve işleme tesisleri civarındaki çevre tahribatının azalacağı muhakkaktır.

Traverten atıklarının, alttemel ve temel tabakalarında kullanılmasının, nakliye maliyeti açısından; traverten ocağına ya da işleme tesisine yakın bölgelerde, traverten atığ1 ve atığ1 uygun gradasyona getirmek için ilave bedel ödenmediği takdirde ekonomik olduğu görülmüştür. Yapılan hesaplamalar, traverten atıklarının elde edilmesi ve agrega boyutuna getirilmesi için hiçbir harcama yapılmaması durumunda bile taşıma maliyetinin kırmataşa göre daha fazla olmasından dolayı mesafe uzadıkça traverten atığ kullanımının kırmataşa göre daha maliyetli hale geldiğini göstermiştir. Ancak; yukarıda bahsedilen çevresel faydası ve civardaki uygun kırmataş ocaklarının sınırlılığı gibi durumlar gözetilerek daha uzak mesafelerde dahi traverten atıklarının yol temel ve alttemel tabakalarının yapımında kullanılması tercih edilebilecektir.

$\mathrm{Bu}$ çalışmada Alaşehir (Manisa) bölgesindeki traverten atıklarının yol üst yapısında alttemel ve temel tabakalarında kullanılabilirliği incelenmiştir. Yapılan çalışmalar ve deneyler sonucunda traverten atığı malzemenin alttemel ve temel tabakalarında teknik olarak kullanılabileceğini göstermiştir.

\section{KAYNAKÇA}

[1].Erkek, D. ve Özdemir, S., "Mermer ve Traverten Sektörüne Küresel ve Bölgesel Yaklaşım. Araştırma Raporu", 2011.

[2].Yıldız, A.H., "Mermer Atıklarının Yol İnşaatında Değerlendirilmesi”, Doktora Tezi, Süleyman Demirel Üniversitesi, Fen Bilimleri Enstitüsü, Isparta, 2008.

[3].Çoruh, E., Hınıslığlu, S., Kocakerim, M., Arasan, S. ve Oltulu, M., "Borojipsin Alt Temel Tabakasında Stabilizasyon Malzemesi Olarak Kullanılmasının Araştırılması", Erzincan Üniversitesi Fen Bilimleri Enstitüsü Dergisi, 6(2), 221-231, Erzincan, 2013.

[4].Çobanoğlu, İ., Çelik, S., Çam, O., Etiz, H., Kurşun, M., Denizli Bölgesi Traverten Artıklarının Beton Agregası Olarak Kullanılabilirliğinin İncelenmesi. Pamukkale Üniversitesi Mühendislik Bilimleri Dergisi, 20(3), 92-99, 2014.

[5].Ural, N. ve Yakşe, G., “Atık Mermer Parçalarının Yol Temel Malzemesi Olarak Değerlendirilmesi”, Şeyh Edebali Üniversitesi, Fen Bilimleri Dergisi, 2 (2), 53-62., Bilecik, 2015.

[6].Yakşe, G., “Atık Mermer Parçalarının Yol Temel Malzemesi Olarak Değerlendirilmesi”, Yüksek Lisans Tezi, Şeyh Edebali Üniversitesi, Fen Bilimleri Enstitüsü, Bilecik, 2016.

[7].Özdemir, E., Sarıcı, D.E. ve Sarıcı, T., "Doğu Anadolu Bölgesinde Bulunan Bazı Mermer Atıklarının Yol Temel ve Alttemel Tabakalarında Kullanılabilirliğinin Değerlendirilmesi”, Dumlupınar Üniversitesi, Fen Bilimleri Enstitüsü Dergisi, Sayı 39, 13-20, Kütahya, 2017.

[8].Yüksek, S., Kaya, S., "Kömür Baca Külü, Kireç ve Jips Ürünlerinden Yapı Malzemesi Yapımı", Akademik Platform Mühendislik ve Fen Bilimleri Dergisi 5(3), 58-70, 2017.

[9].Ergezer, F., "Sıcak Çermik Bölgesi (Sivas) Traverten Atıklarının Yol Temel ve Alttemel Tabakalarında Kullanılabilirliğinin Araştırılması”, Süleyman Demirel Üniversitesi, Fen Bilimleri Enstitüsü Dergisi, Cilt 22, Özel Say1, 181-188, Isparta, 2018.

[10].Yılmaz, F., "Uçucu Kül ve Mermer Tozu Katkılarının Zeminin Stabilizasyonuna ve Donma-Çözülmesine Etkisinin Araştırılması", Akademik Platform Mühendislik ve Fen Bilimleri Dergisi 8(1), 56-61, 2020.

[11].Sarışık, A., Can, S., Ürün, K., Traverten Atıklarının Çimentolu Dolgu Malzemesi Olarak Kullanımında Renk ve Parlaklık Değerlerinin Araştırılması. Dicle Üniversitesi Mühendislik Fakültesi Mühendislik Dergisi, 11(1), 447-455, 2020.

[12].Yonar, F., Dikbaş, A. ve Doğan, I., "Dökümhane Cürufunun Karayolu İnşaatında Dolguda ve Granüler Tabakalarda Kullanım Olanaklarının Araştırılması", 7. Geoteknik Sempozyumu, İstanbul, 22-23-24 Kasım 2017.

[13].Motor, E., "Borojipsin Alttemel Tabakasında Stabilizasyon Malzemesi Olarak Kullanılmasının Araştırılması", Yüksek Lisans Tezi, Atatürk Üniversitesi, Fen Bilimleri Enstitüsü, Erzurum, 2007. 
[14].Seren, I.S., "Elektrik Ark Firını Cürufunun Yapay Agrega Olarak Esnek Üstyapıların Çimento Bağlayıcılı Granüler Temel Tabakasında Kullanılabilirliğinin İncelenmesi”, Yüksek Lisans Tezi, İstanbul Teknik Üniversitesi, Fen Bilimleri Enstitüsü, İstanbul, 2015.

[15].Yılmaz, A. ve Sütaş, İ., "Ferrokrom Cürufunun Yol Temel Malzemesi Olarak Kullanımı", İMO Teknik Dergi, 4455-4470, Yaz1 294, İstanbul, 2008.

[16].Korkmaz, V., "Bor Endüstri Atıkları ve Traverten Atıklarının Çimento Üretiminde Katkı Maddesi Olarak Değerlendirilmesi”, Yüksek Lisans Tezi, Cumhuriyet Üniversitesi, Fen Bilimleri Enstitüsü, Sivas, 2017.

[17].Okubay, M., "Bitümlü Sıcak Karışımlarda Agrega Olarak Mermer Atığı Kullanımının Araştırılması Mermer Atıklarının Bitümlü Sıcak Karışımların Stabilite Özelliklerine Etkisi”, Doktora Tezi, Yıldız Teknik Üniversitesi Fen Bilimleri Enstitüsü, İstanbul, 2016.

[18].Güven, H., "Denizli ve Çevresindeki Traverten Atıklarının Betonda Katkı Malzemesi Olarak Kullanılması", Yüksek Lisans Tezi, Pamukkale Üniversitesi, Fen Bilimleri Enstitüsü, Denizli, 2015.

[19].Ceylan, H. ve Mança, S., "Mermer Parça Atıklarının Beton Agregası Olarak Değerlendirilmesi”, Süleyman Demirel Üniversitesi, Teknik Bilimler Dergisi, Cilt 3, Say1 2, 21-25, Isparta, 2013.

[20].Gürer, C., "Atık Mermer Parçalarının Yol Kaplamalarında Değerlendirilmesi”, Yüksek Lisans Tezi, Afyon Kocatepe Üniversitesi, Fen Bilimleri Enstitüsü, Afyonkarahisar, 2005.

[21].TS EN 1900-1, “İnşaat Mühendisliğinde Zemin Laboratuvar Deneyleri Bölüm 1: Fiziksel Özelliklerin Tayini”, Türk Standartları Enstitüsü, Ankara, 2006.

[22].TS EN 1367-2, “Agregaların Termal ve Bozunma Özellikleri İçin Deneyler Bölüm 2: Magnezyum Sülfat Deneyi”, Türk Standartları Enstitüsü, Ankara, 2011.

[23].TS EN 1097-2, “Agregaların mekanik ve fiziksel özellikleri için deneyler- Bölüm 2: Parçalanma direncinin tayini için yöntemler", Türk Standartları Enstitüsü, Ankara, 2010.

[24].BS 812-105.1, "Testing Aggregates. Method for Determination of Particle Shape- Flakiness Index", British
Standart, England, 1989.

[25].TS EN 1097-6, “Agregaların Mekanik ve Fiziksel Özellikleri İçin Deneyler Bölüm 6: Tane Yoğunluğu ve Su Emme Oranının Tayini” Türk Standartları Enstitüsü, Ankara, 2002.

[26].AASHTO T 89, "Standard Method of Test for Determining the Liquid Limit of Soils", American Association of State and Highway Transportation Officials, 2013.

[27].AASHTO T 90," Standard Method of Test for Determining the Plastic Limit and Plasticity Index of Soils", American Association of State and Highway Transportation Officials, 2014.

[28].TS EN 1744-1, “Agregaların Kimyasal Özellikleri İçin Deneyler Bölüm 1: Kimyasal Analiz”, Türk Standartları Enstitüsü, Ankara, 2010.

[29].TS EN 933-9, “Agregaların Geometrik Özellikleri İçin Deneyler Bölüm 9: İnce Tanelerin Tayini- Metilen Mavisi Deneyi”, Türk Standartları Enstitüsü, Ankara, 2014.

[30].ASTM C 142, "Standard Test Method for Clay Lumps and Friable Particles in Aggregates", American Association of State and Highway Transportation Officials, 2010.

[31].AASHTO T 180, "Standard Method of Test for Moisture-Density Relations of Soils Using a 4.54-kg (10-lb) Rammer and a 457-mm (18-in.) Drop", American Association of State and Highway Transportation Officials, 2018.

[32].Demirel, Z. ve Orhan, F., "Toprak ve Stabilizasyon Laboratuvarı Çalışmaları", Ulaştırma, Denizcilik ve Haberleşme Bakanlığı, Karayolları Genel Müdürlüğü, Ankara, 1994.

[33].AASHTO T 193, "Standard Method of Test for The California Bearing Ratio", American Association of State and Highway Transportation Officials, 2013.

[34].TS EN 1900-2, “İnşaat Mühendisliğinde Zemin Laboratuvar Deneyleri Bölüm 2: Mekanik Özelliklerin Tayini”, Türk Standartları Enstitüsü, Ankara, 2006.

[35].TS 825, "Binalarda Isı Yalıtım Kuralları", Türk Standartları Enstitüsü, Ankara, 2008.

[36].Güven, H., "Denizli ve Çevresindeki Traverten Atıklarının Betonda Katkı Malzemesi Olarak Kullanılması", Yüksek Lisans Tezi, Pamukkale Üniversitesi Fen Bilimleri Enstitüsü, Denizli, 2015. 